OPEN ACCESS

Edited by:

Hajime Kayanne,

The University of Tokyo, Japan

Reviewed by:

Chuki Hongo,

University of the Ryukyus, Japan

Douglas Fenner,

NOAA NMFS Contractor,

United States

*Correspondence:

Natalia Herrán

natalia.herran@/eibniz-zmt.de

Specialty section:

This article was submitted to

Coral Reef Research,

a section of the journal

Frontiers in Marine Science

Received: 30 June 2017 Accepted: 30 November 2017 Published: 13 December 2017

Citation:

Herrán N, Narayan GR, Reymond CE and Westphal $H$ (2017) Calcium Carbonate Production, Coral Cover and Diversity along a Distance Gradient from Stone Town: A Case Study from Zanzibar, Tanzania.

Front. Mar. Sci. 4:412. doi: 10.3389/fmars.2017.00412

\section{Calcium Carbonate Production, Coral Cover and Diversity along a Distance Gradient from Stone Town: A Case Study from Zanzibar, Tanzania}

\author{
Natalia Herrán ${ }^{1,2 *}$, Gita R. Narayan ${ }^{1}$, Claire E. Reymond ${ }^{1}$ and Hildegard Westphal ${ }^{1,2}$ \\ ${ }^{1}$ Geoecology and Carbonate Sedimentology, Biogeochemistry and Geology, Leibniz Centre for Tropical Marine Research \\ (LG), Bremen, Germany, ${ }^{2}$ Geolosciences, University of Bremen, Bremen, Germany
}

Photosymbiotic scleractinian corals are major bioengineers in tropical coastal waters, where they build structurally complex geological features and provide substrata for a manifold of macro and microhabitats. On a local scale, ecological competition and physical parameters - natural as well as human-derived, alter species richness, biodiversity, and morphological adaptation on tropical coral reefs. Here, we compared four coral reefs in the Zanzibar Archipelago at different distances from Stone Town and under different management regimes. To assess the ecological health of these reefs, calcium carbonate production, structural complexity, and $\alpha$-diversity were determined. The unprotected reefs in the direct vicinity of Stone Town, which are exposed to fishing pressure, land-derived pollution, unregulated tourism, and careless anchoring, showed the lowest calcium carbonate production $\left(8.47 \pm 4.37 \mathrm{~kg} \mathrm{CaCO}_{3} \mathrm{~m}^{-2} \mathrm{yr}^{-1}\right)$, coral cover (52.4 $\pm 13.9 \%)$, and diversity $\left(H^{\prime}=0.94 \pm 0.37\right)$. Conversely, the furthest reef and marine protected area showed the highest net calcium carbonate production (16.90 $\left.\pm 9.70 \mathrm{~kg} \mathrm{CaCO}_{3} \mathrm{~m}^{-2} \mathrm{yr}^{-1}\right)$, coral cover $(67.4 \pm 8.7 \%)$, and diversity $\left(\mathrm{H}^{\prime}=1.74 \pm\right.$ 0.20). In comparison to other bioregions and/or reefs of the Indian Ocean, estimates of calcium carbonate production and coral cover (>50\%) were relatively high. Moreover, coral community structure differs significantly with distance from Stone Town, in that, the most homogenous reefs dominated by massive and submassive species (Porites lobata and $P$. rus) occurred the closest to Stone Town.

Keywords: coral reefs, structural complexity, bioerosion, zanzibar archipelago, marine biodiversity, marine protected area (MPA)

\section{INTRODUCTION}

Globally, coastal communities depend on coral reefs as they provide vital ecosystem services such as coastal protection, food acquisition and economic activities such as tourism (Bellwood et al., 2004). However, increasing local anthropogenic (coastal development, pollution and overfishing) and global climate-related pressures greatly threaten coral reefs (McClanahan et al., 2007; Mumby and Steneck, 2008; Graham and Nash, 2013). Reefs affected by local pollution show high framework bioerosion (Edinger, 1998; Holmes et al., 2000) and low skeletal density (Highsmith, 1981), which will limit if not inhibit accumulation of $\mathrm{CaCO}_{3}$ over time. 
The loss of coral cover, reef structural complexity and the associated mechanics are a pressing topic, as coral reefs have declined by $50 \%$ in the last $30-50$ years and it is estimated that $60 \%$ of the world's coral reef ecosystems will disappear over the next 30 years (Hoegh-Guldberg et al., 2007; Burke et al., 2011). The structural complexity of the reef is the foundation of coral reef ecosystems because the inorganic carbonate matrix supports most of the reef biomass (Grigg, 1994). A number of studies have examined the positive relationship between reef structural complexity to biodiversity, biomass and associated ecosystem services (Luckhurst and Luckhurst, 1978; Bellwood et al., 2004; Cinner et al., 2009). In contrast, few studies have examined the actual relationship between coral cover and structural complexity, which is inconsistent with coral cover being the most widespread indicator used in ecological studies for reef health assessment (Jokiel et al., 2015). Most coral reefs show an average live coral cover of no more than 30\% (Vroom, 2011). For example, coral cover in the Caribbean has declined dramatically over the past 30 years, where reefs have declined from about 50 to $10 \%$ coral cover (Gardner, 2003). Coral cover in this region has been correlated with $\mathrm{CaCO}_{3}$ production (Perry et al., 2012, 2015), where Caribbean reefs showed drastically negative trajectories and budgets were estimated to become negative below a threshold of approximately $10 \%$ live coral cover (Perry et al., 2013).

Tropical carbonate secreting benthic assemblages are major bioengineers and sediment producers (Graham and Nash, 2013). Collectively, reef calcifiers produce $7,250 \mathrm{t} \mathrm{CaCO}_{3} \mathrm{~km}^{-2} \mathrm{yr}^{-1}$, with corals dominating carbonate production (73\%) (Hart and Kench, 2007). Calcium carbonate $\left(\mathrm{CaCO}_{3}\right)$ produced within coral reefs accounts for more than $25 \%$ of the total $\mathrm{CaCO}_{3}$ buried in marine sediments globally (Jones et al., 2015). Calcium carbonate sediments are highly important in tropical marine environments because they contribute to reef islands, sand banks and beaches (Kench and Mann, 2017). A number of physical parameters, such as wave exposure, currents and temperature, affect the development of coral reefs, its biodiversity (Roberts et al., 2002) and reef morphology (Mallela et al., 2004; Webb and Kench, 2010; Perry et al., 2013). For instance, platy coral morphologies are more successful on deep fore reef sites, due to their ability to harvest light (Todd, 2008), whereas more robust, boulder corals are generally found in the reef crest under moderate to high hydrodynamic regimes (Storlazzi et al., 2002).

Some hydrozoans, octocorals, sponges and hexacorals have the ability to modify their morphology according to the nutrient, sediment, light or energy regimes in which they occur (Kaandorp and de Kluijver, 1992; Lesser et al., 1994; Sebens et al., 1997; Kaandorp, 1999; Kim et al., 2004; Kaandorp et al., 2005; Kruszynski et al., 2007). It is because of their response to surrounding environmental constraints, that corals morphological strategies are used as bioindicators of water quality (Roberts et al., 2002; Hallock et al., 2004), ecosystem health (Veron et al., 2009), ecological value and conservation priority (Edinger and Risk, 2000). High-resolution standardized census-based datasets can provide further information on coral demography, the population dynamics affecting calcifiers' demography, abundance (Jones et al., 2015) and ecosystem functions (i.e., shelter for marine organisms, coastline protectection, nutrient fixation and cycling) (Perry et al., 2012; Ferrario et al., 2014; Jones et al., 2015). In addition, regional, high-resolution datasets are essential for the overall assessment of reef conditions in a changing ecosystem (Dubinsky and Stambler, 1996).

A range of local stressors have been reported from Zanzibar, from overfishing in Bawe Reef (Lokrantz et al., 2009), pollution in Chapwani and Prison reefs (Moynihan et al., 2012) to mechanical damage by destructive fishing methods such as dragnets (Muhando, 1998; Mohammed et al., 2001) or careless anchoring (Muhando, 1998; Mohammed et al., 2001). At the same time, Zanzibar has a rapid population growth rate (National Bureau of Statistics, 2012) closely linked to the increase in resource demand and tourist infrastructure (Lange and Jiddawi, 2009).

Here we examine coral reef intrinsic factors i.e., biodiversity and structural complexity in some reefs that have received relatively little study (Johnstone et al., 1998). The aim of our study is to assess coral reef condition and determine the effects of local human impacts on hard coral community structure along a distance gradient from Stone Town. To achieve this we aim to: (1) measure the benthic community composition and associated spatial variability, (2) examine the reef structural complexity; (3) determine the net calcium carbonate budget; and (4) use bioindicators i.e., biodiversity indices, coral structural complexity, $\mathrm{CaCO}_{3}$ production and bioerosion rates in coral reefs along an offshore gradient of increasing distance from Stone Town, in western Zanzibar.

\section{MATERIALS AND METHODS}

\section{Study Sites}

The Western Indian Ocean (WIO) region is known to support approximately $21.6 \%$ of the global tropical coral reef area (Burke et al., 2011). Of the total world coral reef coverage, $1.2 \%$ is found in Tanzania, along the East Coast of Africa (UNEP-WCMC 2011). The Zanzibar Archipelago, off continental Tanzania, consists of three major islands including Pemba in the North and Zanzibar (Unguja) and Mafia Islands to the South (Figures 1A,B). The Zanzibar channel acts as a physical barrier, isolating Zanzibar Archipelago from Tanzanian coastal waters (Muzuka et al., 2010) and terrigenous sediments coming from mainland river discharges (Shaghude et al., 2002). Within the region, the annual air temperature ranges between 27 and $35^{\circ} \mathrm{C}$ (Shaghude and Wannäs, 2000) with annual average rainfall of $1,600 \mathrm{~mm}$ on Zanzibar Island (Mgaya, 1997). Southwest-driven monsoonal rains and high currents occur between March to May, while low precipitation and northeastern currents are typical between November and March (Newell, 1957). ROMS models (Regional Oceanic Modeling Systems) show that the semidiurnal mesotidal regime, triggers strong tidal currents from the north and south entrance along the Zanzibar Channel, converging off of Stone Town (Lwiza and Bigendako, 1988; Mukaka, 2014).

Fringing reefs off Stone Town (Figure 1C), located in the western shoreline of Zanzibar Island, are exposed to sewage outfall waters that discharge into coastal waters. The main 


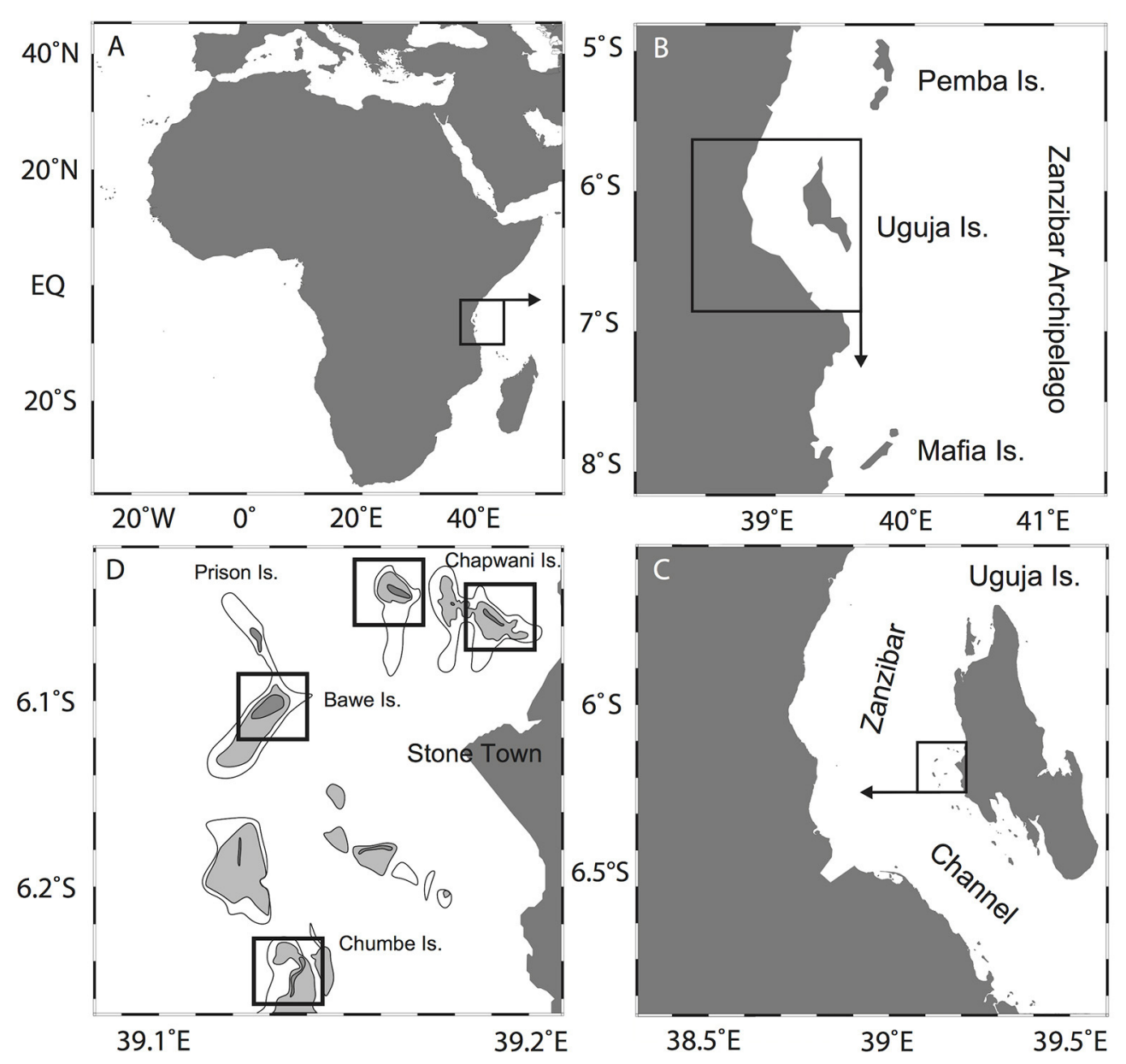

FIGURE 1 | Location of the study area showing (A) the African continent; (B) Zanzibar (Unguja) Island; (C) Zanzibar Archipelago, off of Stone Town; and (D) Zanzibar island chain and location of our study sites.

outfall, located adjacent to the Port of Stone Town, discharges an estimated $2.2 \times 10^{6} \mathrm{~L} \mathrm{~d}^{-1}$ of untreated sewage (Moynihan et al., 2012). Tidal currents distribute the flow of wastewater in a northward direction away from Stone Town toward three nearby reef sites that are important artisanal fishing grounds and tourist destinations (Johnstone et al., 1998; Mohammed and Mgaya, 2001; Mukaka, 2014).

Four of these fringing reefs north of Stone Town are the focus of the present study (Figure 1D). Chapwani Reef $\left(6^{\circ} 7^{\prime} 35.89^{\prime \prime} \mathrm{S}\right.$, $\left.39^{\circ} 11^{\prime} 32.13^{\prime \prime} \mathrm{E}\right)$, Prison Reef $\left(6^{\circ} 7^{\prime} 7.57^{\prime \prime} \mathrm{S}, 39^{\circ} 9^{\prime} 58.90^{\prime \prime} \mathrm{E}\right)$, Bawe Reef $\left(6^{\circ} 8^{\prime} 56.72^{\prime \prime} \mathrm{S}, 39^{\circ} 7^{\prime} 57.04^{\prime \prime} \mathrm{E}\right)$ and Chumbe Island Coral Park (CHICOP) $\left(6^{\circ} 16^{\prime} 42.32^{\prime \prime} \mathrm{S}, 39^{\circ} 10^{\prime} 40.29^{\prime \prime} \mathrm{E}\right)$ are located at increasing distances from Stone Town (approx. 3, 5, 6, and $13 \mathrm{~km}$, respectively). We measured the distance to the reef sites (to the reef slope) from the Institute of Marine Scienes, located adjacent to the Port of Stone Town. Bawe and Chapwani reefs possess welldeveloped fringing reefs along the island's north coast, whereas Prison Reef's main fringing reef faces the northwestern side of the Island. Prison and Bawe reefs are separated from Stone Town by a tidal channel (approx. 20-30 m deep) characterized by strong tidal currents (Mohammed and Mgaya, 2001). CHICOP has been an ecological sanctuary and marine protected area (MPA) since 1994. The high biodiversity and good condition of the reef in the early 90's was the motivation to privately preserve Chumbe coral reef (Nordlund et al., 2013). CHICOP is a strict no-take reef zone area, stretching along the western flank of the Island. Activities include sustainable eco-tourism and marine education among others, with a zero waste policy (Riedmiller, 1998).

\section{Ecological Surveys}

To determine the species composition and calcium carbonate production in our study sites, we applied the line intercept transect method (LIT) (English et al., 1997) and ReefBudget Method (Perry et al., 2012), respectively during a field excursion from August to October 2014. The (5 to $10 \mathrm{~m}$ ) reef slope at each reef site was specifically chosen for being the most productive bioregion with the highest coral biodiversity and it was easily accessible from Stone Town. In addition, the reef slope is commonly studied and can be more easily compared to other reef studies (e.g., Januchowski-Hartley et al., 2017). By convention, 
six 10-m transects were randomly placed and independently recorded by SCUBA divers on the reef slope of each study site at shallow $(5 \pm 2 \mathrm{~m})$ and deep $(10 \pm 2 \mathrm{~m})$ areas, with the exception of Chapwani Reef, where transects were only recorded at $5 \mathrm{~m}$, as the reef slope was bathymetrically constrained to approx. $7 \mathrm{~m}$. The identification of corals was made to the genus and species level where possible, following taxonomic references (Veron, 2000, 2002; Huang et al., 2014) We also recorded the following benthic categories: coralline algae, sponge, corallimorph, others (e.g., seagrass, zoanthids, clams etc.), sub-category 1 (i.e., dead coral and rubble) and sub-category 2 (i.e., sand, mud and silt).

The relative percentage cover of each benthic category was calculated by the fraction it occupies (Xi) $[\mathrm{cm}]$ divided by the total transect $(\mathrm{TL})[\mathrm{cm}]$ multiplied by a factor of 100 . In order to quantify the calcium carbonate production and reef structural complexity, we measured the substrata, benthic taxa and habitat, making use of a high-spatial resolution $(1 \mathrm{~cm})$ substrate analysis (English et al., 1997) and the ReefBudget Method (Perry et al., 2012) to the morphological level. Following the ReefBudget methodology, four morphological classes of coral were distinguished; branching, platy, massive and submasive. We applied density and calcification rates of each morphological group (Perry et al., 2012). We measured $5(50 \times 50 \mathrm{~cm})$ quadrants per transect to measure boring sponge, urchin and crustose coralline algae (CCA) abundance and coverage. We used published data on boring sponge erosion rates (Scoffin et al., 1980; Perry et al., 2012) and the measured abundance to calculate the bioerosion at each location. The sea urchin bioerosion rates were calculated from the abundance data, where we measured 5 different size classes $(0-20 \mathrm{~mm}, 21-40 \mathrm{~mm}$, 41-60 mm, 61-80 mm, 81-100 mm) following Scoffin et al. (1980). To quantify parrotfish bioerosion rates we first measured parrotfish abundance. Secondly, we recorded 4 different size classes: $5-14 \mathrm{~cm}, 15-24 \mathrm{~cm}, 25-34 \mathrm{~cm}, 35-44$ and over $45 \mathrm{~cm}$. Third, we multiplied the parrotfish bite rate, the percentage of bites leaving scars and the volume of carbonate eroded per bite according to the fork size using published data (Bruggemann et al., 1994a,b, 1996; Perry et al., 2012). We assumed that the feeding behavior between Caribbean and Indian Ocean parrotfish were similar between the two regions. Thereafter, we calculated the net or total calcium carbonate production rates as a measure of gross calcium carbonate rates produced by carbonate secreting organisms, i.e., hard corals, CCA and calcifying macroalgae, minus bioerosion rates of parrotfish, sea urchin, boring sponge and micro-bioeroders.

The roughness, reef structural complexity or reef architecture, here defined as the three dimensionality property of the reef framework, was calculated as D1/D2 $[\mathrm{m} / \mathrm{m}]$, where D1 is the contour measured of each substratum or feature and D2 the planar distance covered by the substratum (Hubbard et al., 1990; Harney and Fletcher, 2003; Mallela and Perry, 2006; Perry et al., 2012).

\section{Data Analysis: Statistical Tests}

To test the variance between multiple reef components (e.g., biodiversity indices, reef complexity, coral morphologies and carbonate production rates) to location, distance and depth, multiple two-way ANOVA was performed, considering all the variables. The Tukey's Honest Significant Difference (HSD) posthoc tests were used to determine differences between the reefs. Multiple one-way ANOVA was used to test differences between mean coral cover values on shallow and deep zones at each location. To determine how representative the sampling method was and to validate the sampling strategy used in this study, we computed a rarefaction curve (S.2) of the abundance data using Kindt's exact method described in Oksanen (2015). The alpha diversity (biodiversity) of hard corals is given as the ShannonWiener Index natural log (Equation 1) and Margalef species richness (Equation 2).

$$
\begin{aligned}
H^{\prime} & =\sum_{i=1}^{S}-(P i * L n P i) \\
M & =(S-1) / \log N .
\end{aligned}
$$

Were $P i=$ proportional abundance of genera $i, S=$ number of genus encountered, $\sum=$ sum from genus 1 to genus $S, N=$ total counts.

All analyses were computed with $\mathrm{R}$ software (R Core Team, 2010). We used the following packages: Vegan (Oksanen, 2015), Companion to Applied Regression package (Fox and Weisberg, 2011), BiodiversityR (Kindt and Coe, 2005), tcltk (R Core Team, 2014), ggplot2 (Wickham, 2009) and Modern Applied Statistics with S (Venables and Ripley, 2002).

To describe the benthic beta diversity (distribution patterns of the biodiversity between sites) and to describe the community composition, we ran MDS (non-metric multidimensional scaling), ANOSIM (analysis of similarity) and SIMPER (similarity percentage) analyses on the hard coral relative abundance data (Clarke, 1993). Such analyses were computed with PRIMER-E software v.6 (Plymouth Routines In Multivariate Ecological Research).

\section{RESULTS}

\section{Community Structure and Alpha Diversity}

Our study sites showed high live coral cover (>50\%). Mean live coral cover in shallow reef-slope areas $(5 \pm 2 \mathrm{~m}$ ) was (Mean \pm $\mathrm{SD}, n=6) 52.5 \pm 13.9 \%, 65.8 \pm 10.6 \%, 72.7 \pm 15.1 \%$ to $67.4 \pm$ $8.8 \%$ for Chapwani, Prison, Bawe and Chumbe reefs, respectively. Deeper areas $(10 \pm 2 \mathrm{~m})$ also show high live percentage cover; $74.5 \pm 13.3,71.5 \pm 12.8$, and $57.6 \pm 17.9 \%$ for Prison, Bawe and Chumbe reefs, respectively. Overall, there were significant differences of live cover between depths at Prison Reef (one-way ANOVA, $F_{1-4}=19.74, p=0.011$ ) and Chumbe Reef (one-way ANOVA, $\left.F_{1-4}=10.31, p=0.032\right)$, but not at Bawe Reef $(p>$ 0.05 ) second most abundant benthic category was dead coral and coral rubble (Sub-category $1,>12 \%$ ), but at Chapwani and Prison Reef the second dominant benthic category in shallow reef-slope areas was Hexacorallia, order Corallimorpharia STEPHENSON, 1937. In total 33 hard coral taxa were observed when all transects were pooled (Figure S1). At Chapwani Reef 10 hard coral taxa were observed, whereas in Prison, Bawe and Chumbe reefs a total of 20,21 , and 27 taxa were observed, respectively following the most recent taxonomic revision (Huang et al., 2014). Biodiversity and richness increased southwards from Chapwani Reef to 
Chumbe Reef (Table 1). In addition, deeper areas showed lower biodiversity than shallower areas, with the exception of Prison Reef (Table 1). Chumbe Reef has the highest Shannon-Wiener diversity $\left(\mathrm{H}^{\prime}=1.74 \pm 0.20\right.$ and $\mathrm{H}^{\prime}=1.50 \pm 0.25$ at 5 and $10 \mathrm{~m}$, respectively) and Margalef richness $(M=2.35 \pm 0.35$ and $M=2.01 \pm 0.40$ at 5 and $10 \mathrm{~m}$, respectively). However, no significant difference in Shannon-Wiener diversity or Margalef richness indices were found between reefs and depths [two-way ANOVA, $\left.\mathrm{F}_{(3,35)}=2.324, p=0.0918\right]$.

Chapwani, Prison and Bawe reefs were dominated by Porites rus FORSKÅL, 1775, accounting for 50.7, 40.8, and $47.4 \%$ of the relative abundance, respectively (Table $\mathbf{S 1}$ ). Galaxea spp. OKEN, 1815 was the second most abundant taxon at Prison Reef and third most abundant taxon at Bawe Reef (S.1). The relatively high abundance of Pocillopora spp. at Bawe (6.4\%) and Chapwani (6\%) was similar between the two reefs. Branching coral Acropora spp. OKEN, 1815 was the most abundant coral taxa in Chumbe Reef, accounting for $31.6 \%$ of the total relative abundance. Porites lobata, Acropora spp. and P. rus along with Seriatopora sp. and Fungia spp. were found in the shallow reef areas, whereas Galaxea spp., Pocillopora spp. and Porites cylindrica were found generally in deeper reef areas (Table S1). No significant differences were found between shallow and deeper communities (55.77\%).

At transect-scale we identified five distinct benthic goups (Figure 2A). The hard coral community composition in all locations has at least $20 \%$ percent overlap (Bray-Curtis dissimilarity matrix) (Figure 2). Groups 1 and 2 were characterized by $P$. rus, Galaxea spp. and P. cylindrica as dominant taxa. Group 3 was the cluster which included a diverse range of species (Seriatopora and Pocillopora) from all locations. This group shared the occurrence of a large range of coral genera, without a clear dominant taxon. Groups 4 and 5 were dominated by Acropora spp. and large Millepora spp. colonies. Overall, in Chumbe Reef, extensive Acropora spp. fields and distinctive coral species drove dissimilarities in benthic community composition between the reefs (Figure 2).

\section{Morphological Strategies and Reef Structural Complexity}

At all locations, platy corals were the least common morphotype (Figure 3). In Chapwani Reef this class was completely absent, whereas in Prison Reef small Montipora sp. and platy morphotypes of $P$. rus were recorded (Figure 4). Pooled data show that platy coral coverage in Prison Reef was relatively low (1.05\%) compared to other reefs where platy corals had the most cover, for example in Bawe Reef (4.6\%) and Chumbe Reef (5.2\%). Massive and submassive corals were the most abundant morphotypes among the reefs (Figure 3), with the exception of Chumbe reef where we found high branching coral percentage cover $(47.7 \%)$.

We found significant spatial differences in hard coral morphological strategies between reefs (Figure 3). Among all sites, we found high abundance and large colonies ( $>1 \mathrm{~m}$ diameter) of massive corals Porites spp. Strong spatial distribution differences were recorded for submassive and
TABLE 1 | Comparative table showing the mean and standard deviation and range in values for the Shannon-Wiener biodiversity index and Margalef richness.

\begin{tabular}{lcccc}
\hline Location & \multicolumn{4}{c}{ (Mean \pm SD) } \\
\cline { 2 - 5 } & Shannon (In) & Margalef & Range (H') & Range (M) \\
\hline Prison 5 m & $1.16 \pm 0.44$ & $1.42 \pm 0.72$ & $0.63-1.76$ & $0.69-2.73$ \\
Prison 10 m & $1.39 \pm 0.47$ & $1.84 \pm 0.86$ & $0.98-2.16$ & $1.11-3.24$ \\
Bawe 5 m & $1.17 \pm 0.33$ & $1.55 \pm 0.56$ & $0.72-1.64$ & $0.80-2.52$ \\
Bawe 10m & $1.07 \pm 0.33$ & $1.39 \pm 0.45$ & $0.82-1.38$ & $0.86-1.89$ \\
Chumbe 5 m & $1.74 \pm 0.20$ & $2.34 \pm 0.49$ & $1.47-2.04$ & $1.55-2.95$ \\
Chumbe 10 m & $2.01 \pm 0.40$ & $1.84 \pm 0.86$ & $1.51-2.58$ & $1.13-2.27$ \\
Chapwani & $1.46 \pm 0.64$ & $1.14 \pm 0.46$ & $0.43-2.65$ & $0.43-1.89$ \\
\hline
\end{tabular}

branching corals, $F_{3-38}=16.04, p=6.79 \mathrm{e}-07 ; F_{3-38}=7.197, p$ $=0.00061$, respectively (Figures 3, 4).

Reef structural complexity or reef rugosity ranged from 1.18 to 1.51. Among all reefs, structural complexity was slightly higher at shallower rather than deeper areas of the reef slope. With the exception of Prison Reef, which presents higher reef complexity in deeper areas $(1.47 \pm 0.33$ at $5 \pm 2 \mathrm{~m}$ and $1.51 \pm 0.24$ at 10 $\pm 2 \mathrm{~m}$ ). Prison Reef shows the highest reef structural complexity followed by Chumbe, Bawe, and Chapwani reefs ( $1.38 \pm 0.12$, $1.35 \pm 0.48$, and $1.22 \pm 0.28$, respectively at $5 \mathrm{~m}$; Table 2 ). However, the reef complexity was not significantly different by location and by depth $\left[F_{(3,35)}=1.763, p=0.172\right]$.

\section{Bioeroders}

Corallivores were the major biogenic group (Table 3). A large variability of parrotfish bioerosion rates was recorded between and within reefs, which ranged from $(0.44 \pm 0.8$ to $4.97 \pm$ $\left.8.00 \mathrm{~kg} \mathrm{CaCO}_{3} \mathrm{~m}^{-2} \mathrm{yr}^{-1}\right)$. We surveyed parrotfish presence, sea urchin abundance and boring sponge (Figure S2) density. The relatively high sponge abundance and cover found at Bawe $(2.52 \pm 3.61 \%)$ and Prison $(2.52 \pm 3.02 \%)$ reefs contrasts with the relatively low sponge coverage found at Chumbe $(1.30 \pm$ $1.84 \%)$ (Figure 5) and Chapwani (1.05 $\pm 1.80 \%)$ reefs. There were no significant differences between calculated bioerosion rates of boring sponge in Prison and Bawe reef, which show similar bioerosion rates; $0.46 \pm 0.19$ and $0.46 \pm 0.19 \mathrm{~kg} \mathrm{CaCO}$ $\mathrm{m}^{-2} \mathrm{yr}^{-1}$, respectively. However, Chapwani Reef presents very low coverage and thus erosion from boring sponge $(0.02$ $\pm 0.01 \mathrm{~kg} \mathrm{CaCO} 3 \mathrm{~m}^{-2} \mathrm{yr}^{-1}$; Figure 5, Table 3). Conversely, Chapwani Reef showed very high sea urchin abundance and bioerosion rates $\left(1.33 \pm 0.18 \mathrm{~kg} \mathrm{CaCO}_{3} \mathrm{~m}^{-2} \mathrm{yr}^{-1}\right)$, which were significantly different from sea urchin abundance and bioerosion rates in Prison $(p<0.001)$, Bawe $(p<0.001)$ and Chumbe reefs $(p<0.001)$ (Figure 5). Micro-bioerosion rates $\left(<0.0001 \mathrm{~kg} \mathrm{~m}^{-2} \mathrm{yr}^{-1}\right)$ are very low when compared to the rates calculated for macro-bioeroders on a reef-scale (Figure 5).

\section{Calcium Carbonate Production}

Along the western coast of Zanzibar the main carbonate producers are photosynthetic hermatypic corals. We calculated little carbonate production from crustose coralline algae (CCA) 


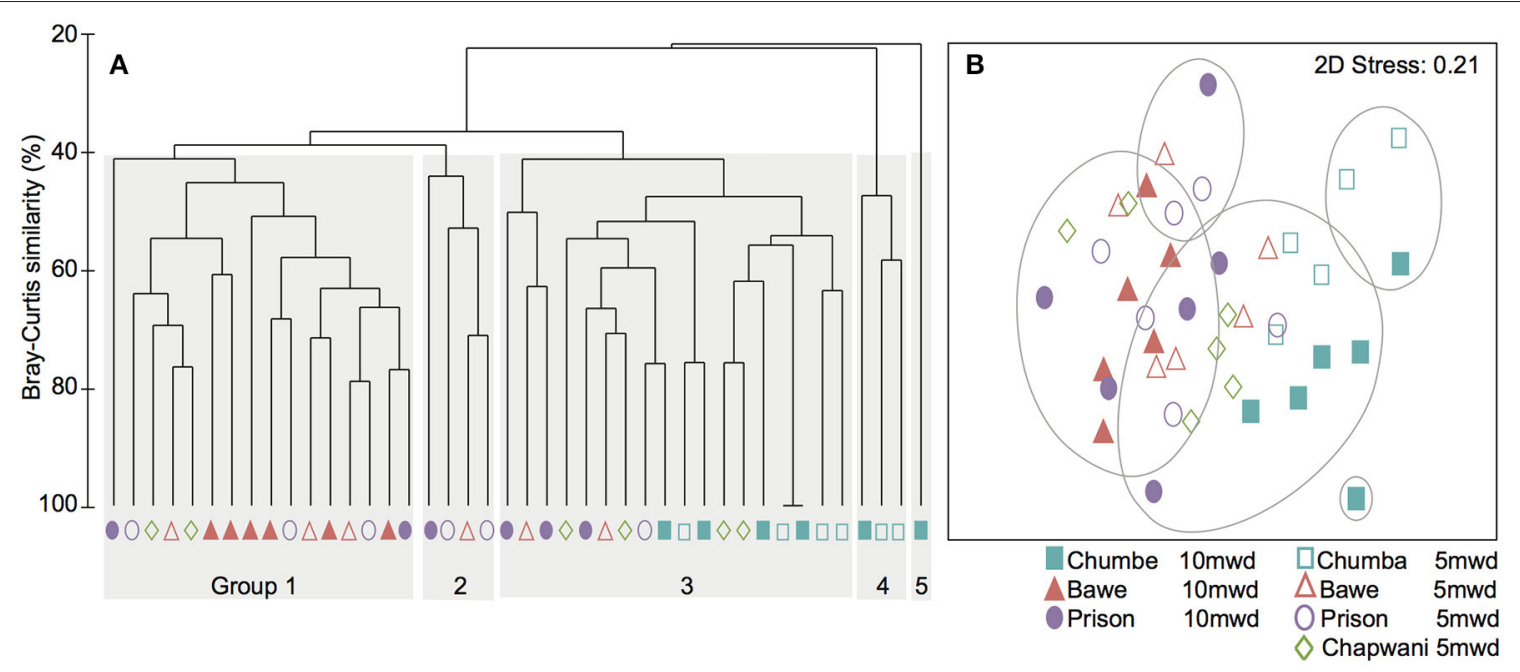

FIGURE 2 | (A) Cluster analysis showing the different groups according to the hard coral composition analysis. (B) The MDS ordination plot of the coral abundance data.
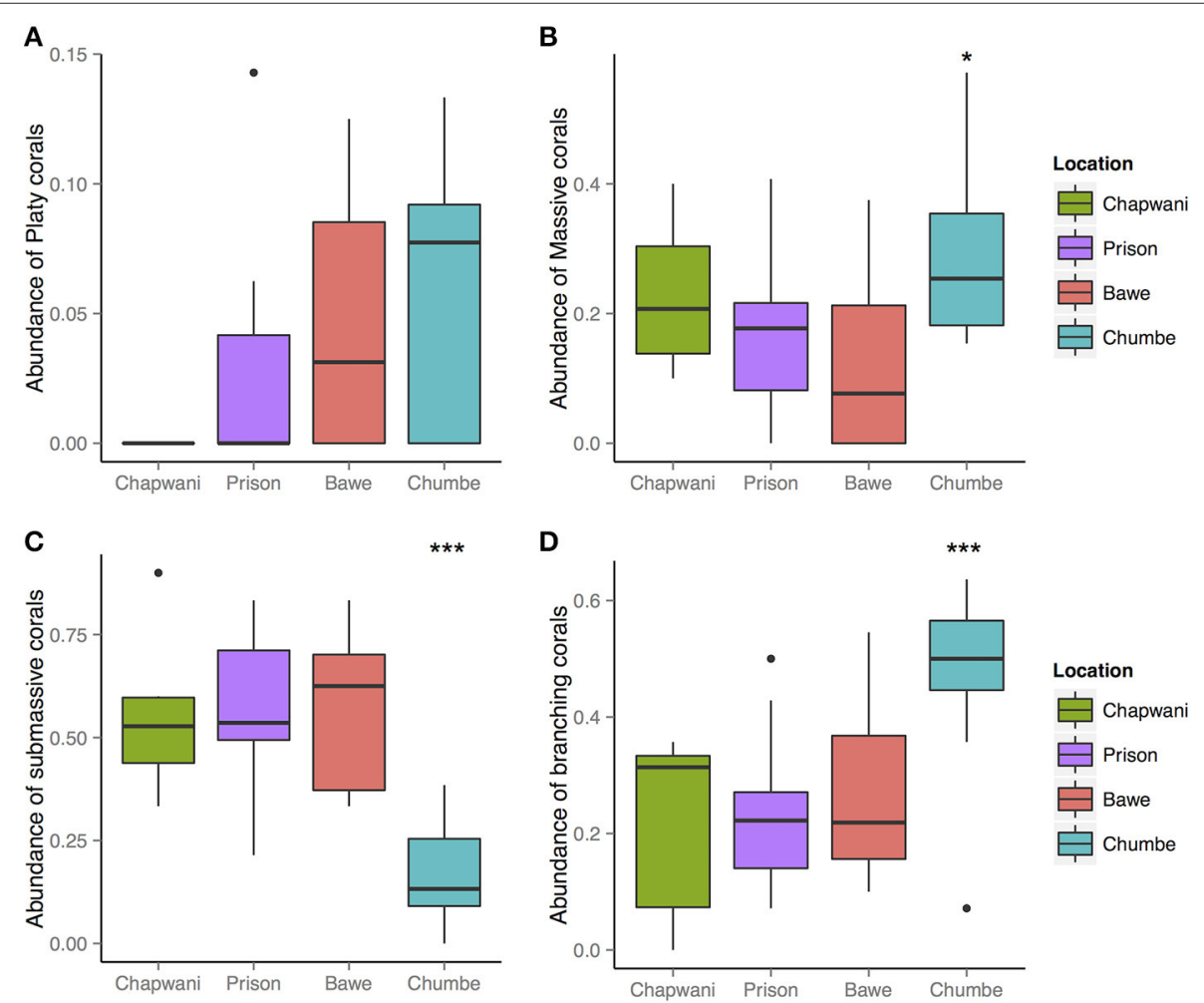

FIGURE 3 | Overview of the hard coral morphological categories: (A) platy; (B) massive; (C) submassive; and (D) branching corals. An analysis of variance showed significant differences between the massive, submassive, and branching coral morphologies $F_{3-38}=4.257, p=0.0109^{\star} ; F_{3-38}=16.046 .79 e-07^{\star \star \star} ;$ and $F_{3-38}=$ 7.197, $p=0.00061^{\star \star \star}$, respectively. However, the distribution of platy corals do not show strong spatial differences $F_{3-38}=2.444, p=0.078$.

and almost no carbonate production from calcifying algae. The reef with the highest CCA percentage cover was Chumbe Reef (approx. 2\%). Negligible occurrence was recorded on the other reefs $(<0.05 \%)$.
Our study sites scored consistently high gross calcium carbonate production rates, $10.7 \pm 4.09,10.43 \pm 2.37,15.03 \pm$ 7.76 , and $18.95 \pm 9.70 \mathrm{~kg} \mathrm{CaCO}_{3} \mathrm{~m}^{-2} \mathrm{yr}^{-1}$, at Chapwani, Prison, Bawe and Chumbe, respectively. The results showed that the 


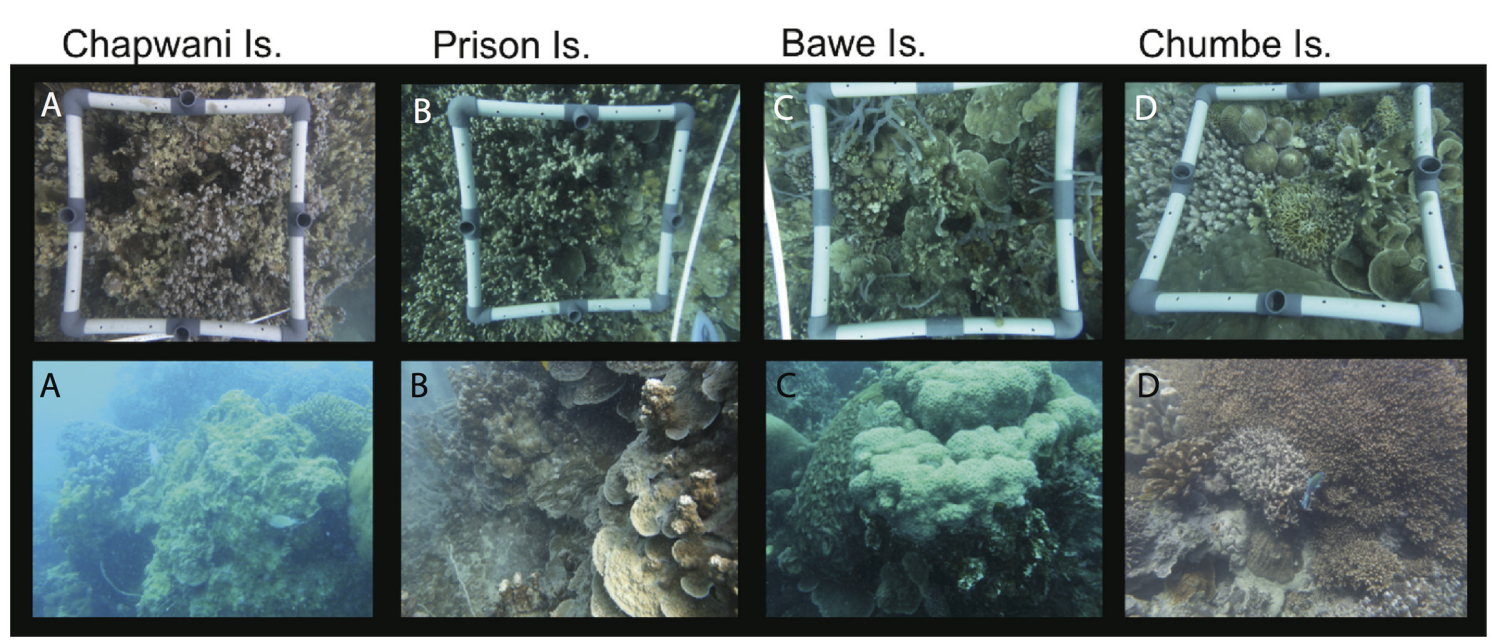

FIGURE 4 | Representative quadrants (0.5 × $0.5 \mathrm{~m})$ taken on (A) Chapwani (Porites rus); (B) Prison (Porites rus); (C) Bawe (Callyspongia spp., Pocillopora spp., Montipora spp.) and (D) Chumbe (Porites lobata, Acropora spp., Seriatopora spp., Montipora spp., Porites cylindrica, and Ctenactis spp.) reef.

TABLE 2 | Comparative table showing the reef structural complexity or rugosity measured at the study sites.

\begin{tabular}{lcc}
\hline Location & Complexity Mean \pm SD & Depth (m) \\
\hline Prison & $1.47 \pm 0.33$ & 5 \\
Prison & $1.51 \pm 0.24$ & 10 \\
Bawe & $1.35 \pm 0.48$ & 5 \\
Bawe & $1.18 \pm 0.13$ & 10 \\
Chumbe & $1.38 \pm 0.12$ & 5 \\
Chumbe & $1.34 \pm 0.23$ & 10 \\
Chapwani & $1.22 \pm 0.28$ & 5 \\
\hline
\end{tabular}

gross calcium carbonate production increased with distance from Stone Town (Figure 6) and was significantly different between reef sites $\left[F_{(3,35)}=3.459, p=0.027\right]$, but carbonate budgets were not significantly different when shallow and deep areas were compared $\left[F_{(1,35)}=0.066, p=0.799\right]$. When we compared one to one gross calcium carbonate production rates, Chumbe Reef production differed significantly from the production recorded in Prison Reef and Chapwani Reef $(p=0.004$ and $p=0.020$, respectively). However, when we compared production rates found in Bawe Reef to those found in Chumbe or Prison reefs we did not see significant differences $(p=0.161$ and $p=0.114$, respectively).

Our study sites show high net calcium carbonate production rates (Gross production rates - bioerosion rates) ranging from $8.03 \pm 4.37$ to $16.90 \pm 9.70 \mathrm{~kg}$ $\mathrm{CaCO}_{3} \mathrm{~m}^{-2} \mathrm{yr}^{-1}$. The $\mathrm{CaCO}_{3}$ production was positively correlated to biodiversity $(p=0.010)$ (Figure 7) and increases with increasing distance to Stone Town ( $p$ $=0.003$ ) (Figure 6). Chapwani, Prison and Bawe reefs dominated by massive and submassive species show high net carbonate production rates $8.03 \pm 4.37 ; 9.8 \pm 2.4$ and $14.11 \pm 7.36 \mathrm{~kg} \mathrm{CaCO}_{3} \mathrm{~m}^{-2} \mathrm{yr}^{-1}$, respectively. However, the no-take zone of Chumbe Reef, dominated by branching ramose Acropora spp. shows the largest net calcium carbonate production (Figure 8).

\section{DISCUSSION}

\section{Community Composition}

Chronic stress has conspicuous consequences for coral reef community structure, recovery and resilience (Nyström and Folke, 2001) and can be exacerbated by compounding local pressures including nutrients, sedimentation, and temperature anomalies. Previous studies have suggested that nutrient levels primarily control coral community structure (Fabricius, 2005; Lapointe et al., 2011), however, nutrient variability is high and concentrations are low in western Zanzibar reefs (Narayan et al., in review). Regular boat traffic is a possible cause of sediment resuspension observed on the shallow reef areas (based on field observations) at Chapwani Reef. Additionally, recent temperature anomalies have seen massive die backs since the 1998 bleaching event throughout the Zanzibar Archipelago (Muhando and Lanshammar, 2008). The proximity to source pollution could have a significant influence on the current community structure and future resilience to local and global stresses.

The community composition of corals found on the reefs adjacent to Stone Town are depauperate and dominated by P. rus. This could be related to local stressors, i.e., land-based pollution and unregulated tourism (Moynihan et al., 2012). Chapwani Reef showed the lowest coral cover $(52.4 \pm 13.9 \%)$, biodiversity $\left(\mathrm{H}^{\prime}\right.$ $=1.2 \pm 0.5)$ and calcium carbonate production $(8.5 \pm 4.4 \mathrm{~kg}$ $\left.\mathrm{CaCO}_{3} \mathrm{~m}^{-2} \mathrm{yr}^{-1}\right)$. In addition, Chapwani Reef showed low CCA relative abundance $(<0.05 \%)$, which is known to limit coral larvae settlement (Vermeij et al., 2011), reef calcification (Fabricius and De'ath, 2001), and overall coral reef recovery. Low CCA abundance has been reported at Chapwani and Prison 
TABLE 3 | Key biogenic groups and microboring bioerosion rates.

\begin{tabular}{|c|c|c|c|c|c|c|c|}
\hline Bioerosion rates $\left[\mathrm{kgCaCO}{ }_{3} / \mathrm{m}^{2} / \mathrm{yr}\right]$ & Prison $5 \mathrm{~m}$ & Prison $10 \mathrm{~m}$ & Bawe $5 \mathrm{~m}$ & Bawe $10 \mathrm{~m}$ & Chumbe $5 \mathrm{~m}$ & Chumbe $10 \mathrm{~m}$ & Chapwani \\
\hline Sp. Bioerosion & $0.63 \pm 0.81$ & $0.46 \pm 0.19$ & $0.39 \pm 0.23$ & $0.45 \pm 0.29$ & $0.13 \pm 0.05$ & $0.47 \pm 1.88$ & $0.02 \pm 0.01$ \\
\hline Urchin Bioerosion & $0.03 \pm 0.04$ & $0.03 \pm 0.05$ & $0.76 \pm 0.61$ & $0.14 \pm 0.16$ & 0.00 & 0.00 & $1.33 \pm 0.18$ \\
\hline Microbioeroders & $0.04 \pm 0.04$ & $0.02 \pm 0.03$ & $0.04 \pm 0.04$ & $0.03 \pm 0.02$ & $0.05 \pm 0.01$ & $0.06 \pm 0.02$ & $0.10 \pm 0.03$ \\
\hline Parrot bioerosion & \multicolumn{2}{|c|}{$0.55 \pm 1.75$} & \multicolumn{2}{|c|}{$4.97 \pm 8.00$} & \multicolumn{2}{|c|}{$1.80 \pm 3.04$} & $0.44 \pm 0.80$ \\
\hline
\end{tabular}

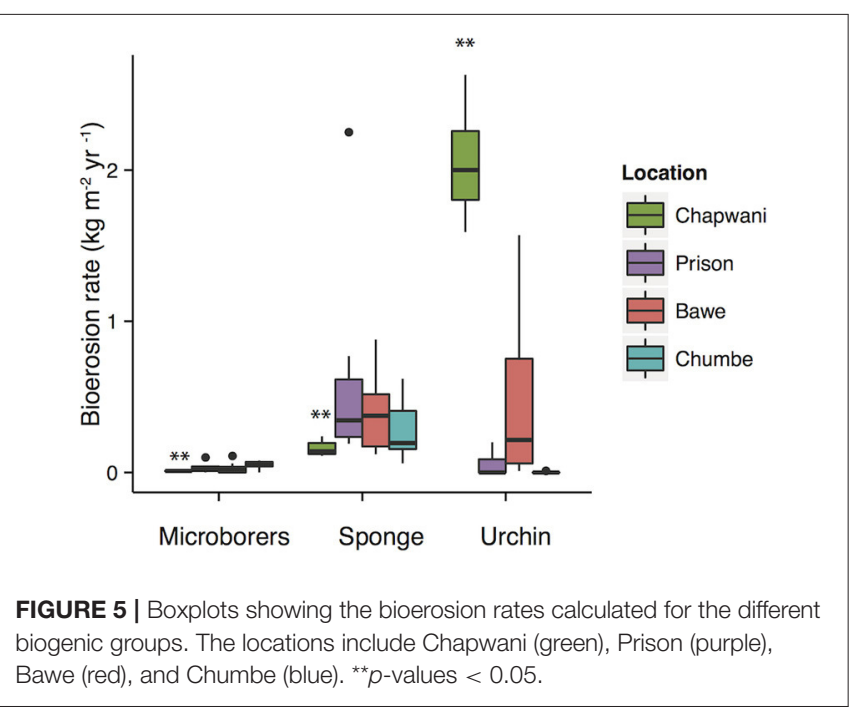

reefs (Szmant, 2002), which is consistent with our findings. CCA and stony coral demography are usually closely linked as those organisms require similar environmental conditions. Therefore the abundance and occurrence of CCA is commonly used as a bioindicator for water quality in coral reef studies (Vermeij et al., 2011). In addition, the impoverished benthic diversity on those reefs, indicate suboptimal (e.g., turbid or polluted waters) coral reef conditions (Szmant, 2002) and/or high sediment stress (Fabricius and De'ath, 2001).

In 1998 and 2005 Chumbe Reef was heavily affected by bleaching events (Muhando and Lanshammar, 2008). In 1998, $90 \%$ of the branching corals (mainly P. cylindrica and Acropora spp.) were affected and $50 \%$ of them were reported dead (Muhando, 1999; Mohammed et al., 2001; Muhando and Lanshammar, 2008). In 2005, shallow Acropora fields were also strongly impacted, consistent with reports that Acropora spp. are less resistant to bleaching (McClanahan et al., 2007). However, in a few years corals recovered their functionality and community structure at Chumbe Reef (McClanahan et al., 2007). In contrast limited recovery was generally found after the 1998 bleaching event on heavily exploited reefs globally which were subjected to fishing pressures and/or pollution (Wilkinson, 2008). Unfortunately, we cannot establish the recovery level at Chapwani, Prison and Bawe reefs after the 1999 and 2005 bleaching events as there is no information about reefs in the Zanzibar Archipelago other than Chumbe for this period of time.

The morphological plasticity of $P$. rus may favor the dominance of this particular coral species in Chapwani Reef,
Prison Reef and to a certain extent at Bawe Reef (Figures 3, 4). This coral species has been found in its submassive, branching, and platy forms in all three locations. We suspect that this coral species is highly resilient and therefore dominant in the reefs close to Stone Town. Presumably, corals adjust their skeletal shape to the main constraining environmental factors that control morphological specialization in corals, e.g., light intensity, water movement and sedimentation rates (Todd, 2008). Furthermore, our findings suggest that this mechanism drives beta diversity in our study sites as we found small scale (colony level) differences in the morphological strategies among sites (Figure 3). All study sites are protected from swells (Shaghude et al., 2002) and tides have an equal effect on all the study sites. Tidal-induced currents although energetic ( 5 to $20 \mathrm{~cm} \mathrm{~s}^{-1}$ ), would not mechanically break corals, in contrast to wave-exposed coral reefs (Todd, 2008).

Chumbe Reef showed the highest biodiversity values ( $H^{\prime}$ $=1.74 \pm 0.20)$ whereas Chapwani and Prison reefs scored consistently low $\left(\mathrm{H}^{\prime}=0.94 \pm 0.37\right)$ to medium $\left(\mathrm{H}^{\prime}=1.16\right.$ \pm 0.44 ) biodiversity values when compared to other studies. We did not find a clear relationship between coral cover and structural complexity, which could be explained by the high coral cover measured when specific genera were dominant. For example on shallow Acropora spp. fields in Chumbe Reef or $P$. rus dominated fore reefs (at Prison and Chapwani reefs), the structural complexity remained low. However, we found that the roughness significantly increased with $\alpha$-diversity. This was the case in Bawe Reef, where reef complexity was strongly correlated to biodiversity metrics ( $p=0.0005)$.

We propose the use of biodiversity indices instead of live percentage coral cover or structural complexity (discussed above) as a discrete proxy for ecosystem health in the Western Indian Ocean. High coral cover favored by benthic ecological competition due to limited substrate availability has been reported from some locations with turbid waters. Similar results were found in nearshore reefs at the GBR, where hard coral cover was two times higher than mid- and outer-shelf reefs (Morgan et al., 2016). However, biodiversity indices gave us a finer overview; consistent with other studies reporting reduced biodiversity values close to highly populated cities in the coral triangle (Edinger et al., 1998).

Overall, the reefs studied showed moderate to excellent health; outstanding reef condition was estimated in Chumbe Reef and proved to be in agreement with other studies (McClanahan et al., 2007). $\mathrm{CaCO}_{3}$ values $\left(16.90 \pm 9.70 \mathrm{~kg} \mathrm{CaCO}_{3} \mathrm{~m}^{-2} \mathrm{yr}^{-1}\right)$, coral cover $(67.37 \pm 8.76 \%)$, reef structural complexity $(1.36 \pm 0.17)$ and medium-high biodiversity $\left(\mathrm{H}^{\prime}=1.74 \pm 0.20\right.$ and $\mathrm{H}^{\prime}=1.50$ 


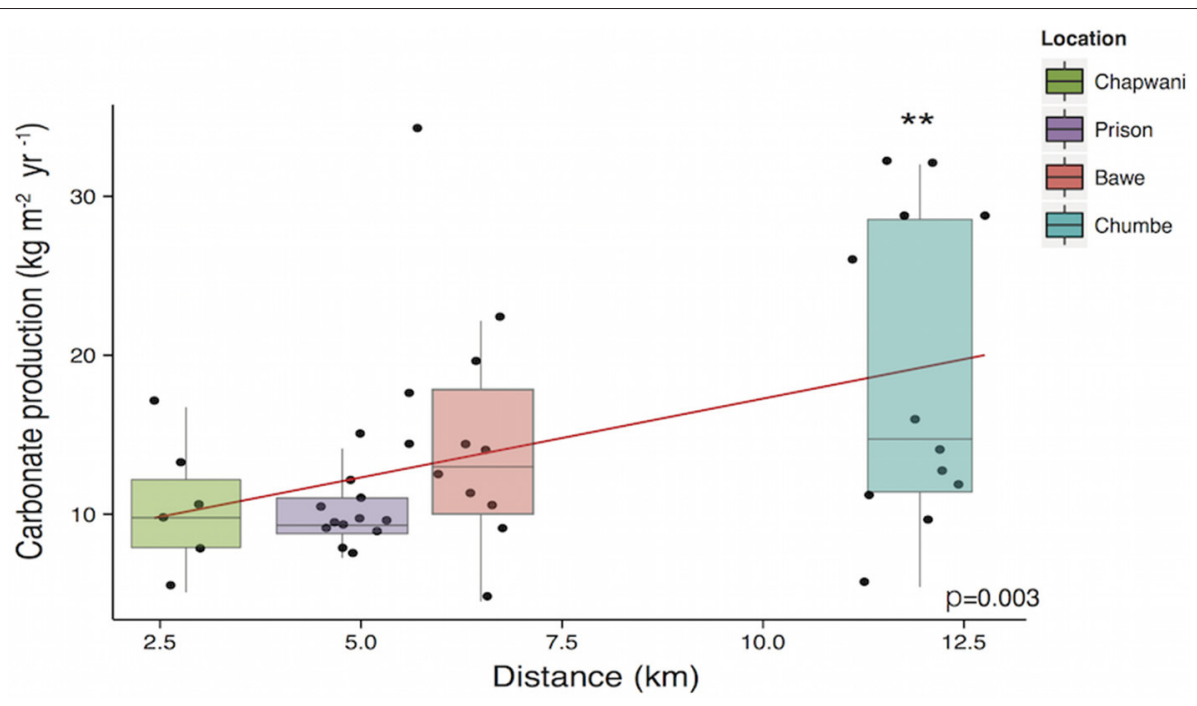

FIGURE 6 | Boxplot showing the gross calcium carbonate production per reef at 5 and $10 \mathrm{~m}$. The linear regression model shows the correlation between the calcium carbonate production and distance to Stone Town. ${ }^{* *} p$-values $<0.05$.

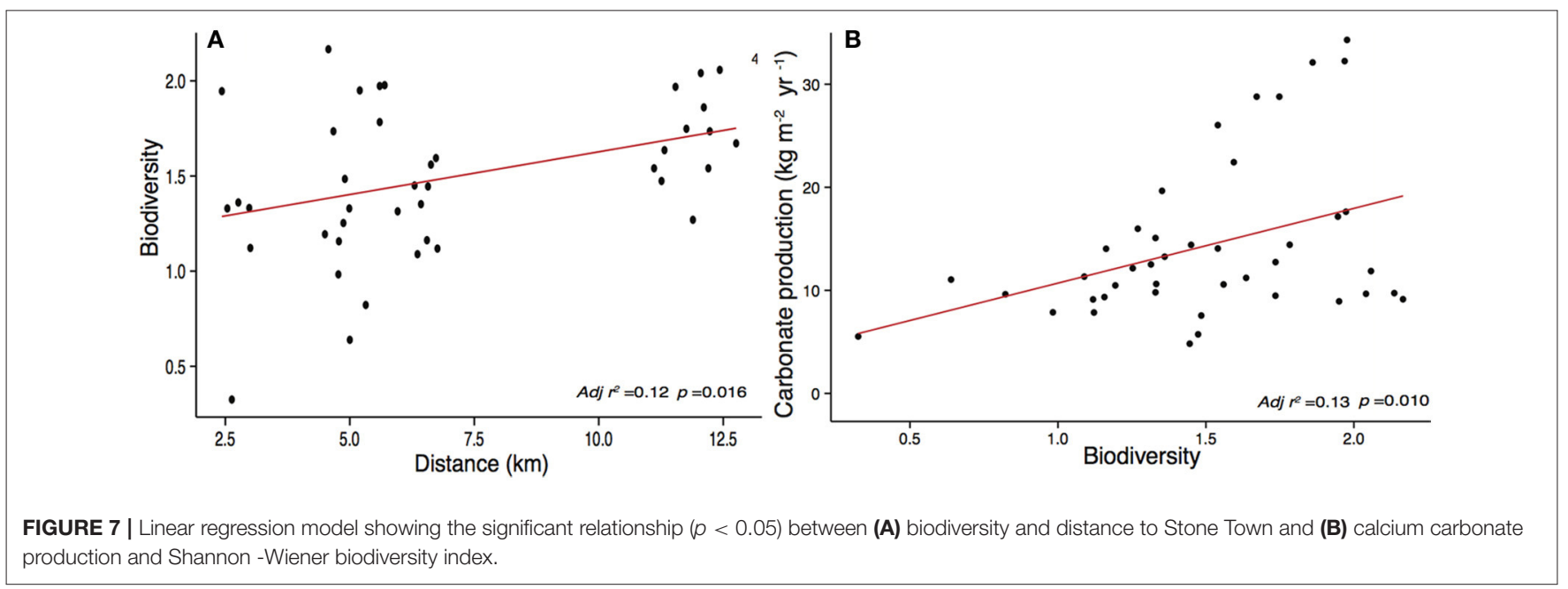

\pm 0.24 at 5 and $10 \mathrm{~m}$, respectively) and richness $(M=2.3 \pm$ 0.41 ) could be used as reference outer shelf coral reefs in the Western Indian Ocean. For example, Madang lagoon in Papua New Guinea is considered to have medium-high biodiversity $\left(\mathrm{H}^{\prime}\right.$ $=1.11$ ), whereas Bunaken National Park, Indonesia has high biodiversity ( $H^{\prime}=1.65$ ) (Fuad, 2010) and high coral cover (46\%), and biodiversity values that are similar to CHICOP.

\section{Calcium Carbonate Production and Reef Complexity}

The model used to quantify calcium carbonate production gave us a good overview of the different biogenic groups crucial to produce, maintain and shape coral reef framework. We were able to quantify and assess the main community composition and compare them with global reefs by using keystone (i.e., sea urchin and parrotfish) species as ecological bio-indicators. Overall, we found a strong gradient that explained the calcium carbonate production in relation to distance to Stone Town (Figure 7). When compared to global carbonate budgets, Zanzibar's carbonate reefs are very productive (Figure 8; $>8 \mathrm{~kg}$ $\left.\mathrm{CaCO}_{3} \mathrm{~m}^{-2} \mathrm{yr}^{-1}\right)$. Among the reefs examined by this study, CHICOP (Chumbe Island Coral Park) marine protected area (MPA) stands out with high live percentage coral cover and a high calcium carbonate production rate $\left(16.95 \mathrm{~kg} \mathrm{CaCO}_{3} \mathrm{~m}^{-2} \mathrm{yr}^{-1}\right)$. Similar production rates have been reported within Caribbean MPAs. Bonaire, for instance, scored $16.68 \mathrm{~kg} \mathrm{CaCO}_{3} \mathrm{~m}^{-2} \mathrm{yr}^{-1}$ (Figure 8).

Ecological interactions and ultimately bioerosion are key processes which shape reef geomorphology (Mallela et al., 2004). The classification and quantification of bioeroders has been discussed in the literature (Highsmith, 1981; Hutchings, 1986; Edinger et al., 2000; Holmes et al., 2000; Glynn and Manzello, 2015). We primarily measured parrotfish, urchins 


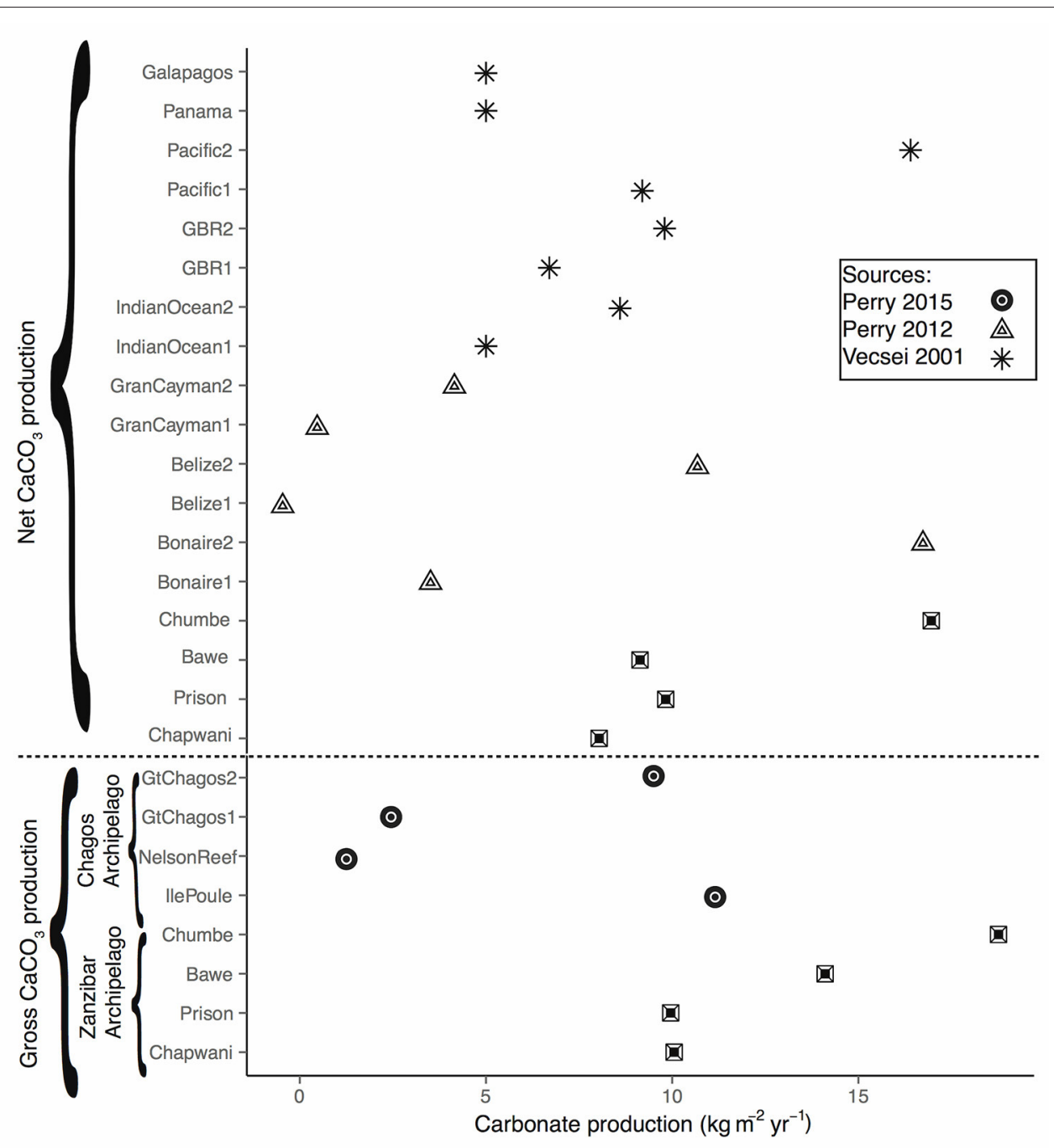

FIGURE 8 | Global comparison showing the $\mathrm{CaCO}_{3}$ production at different locations. Filled dots present the gross calcium carbonate production in our study sites, squares show the gross calcium carbonate at Chagos Archipelago, as presented sensu (Perry et al., 2015), triangles shows the net calcium carbonate according to Perry et al. (2012) The numbering 1 and 2 indicate the minimum and maximum value. Asterisks represent the source Vecsei (2001). The numbering 1 and 2 indicate, either low or high ramose corals.

and boring sponges as they strongly affect reef community structure (Figure S2) and reef structural complexity (Mumby et al., 2006; Graham and Nash, 2013). We also estimated the effect of microborers, but when compared to sea urchins and corallivorous fishes, their effect was negligible. Prison Reef showed higher structural complexity than Bawe Reef, which suggests greater reef maturity (Graham and Nash, 2013). However, we observed that relatively high bioerosion and/or poorly cemented framework could lead to high structural complexity though the break-down and disintegration of the reef framework at Prison Reef (Figure S3). Therefore, crude measurements of structural complexity might lead to misleading ecosystem health interpretations since we associate high structural complexities to healthy and functional reefs (Graham and Nash, 2013).

In addition, Zanzibar's fringing reefs are spatially constrained to areas that were previously colonized by hard corals since hard surfaces are necessary for settlement of coral larvae (Wolanski et al., 2003; Fabricius, 2005). Thus, due to reduced recruitment, reef expansion in turbid settings takes place through the breakdown and collapse of the fore-reef flank (Tudhope and Scoffin, 1994). Yet, initial disturbances causing coral mortality do not necessarily affect reef structure immediately (Graham et al., 2009). In the years that follow major coral mortality, the reef complexity will potentially deteriorate. For example, structural changes after the 1998 bleaching event happened in a time spam of 5-6 years (Graham et al., 2006, 2009).

\section{MPA Relevance and Implication for Management}

Zanzibar has shown rapid population growth rates (National Bureau of Statistics, 2012), an increase of tourist infrastructures (Jiddawi and Ohman, 2002) and coastal development in the past decade. Coastal development in particular affects water 
quality by increasing turbidity and the sediment load in the water column (Mumby et al., 2006) and has been well established to have a direct effect on coral community structure (Fabricius, 2005). Chapwani and Prison already show signs of pollution (Moynihan et al., 2012) and destructive fishing such as dragnets (Muhando, 1998; Mohammed and Mgaya, 2001) have been reported. Both natural and anthropogenic stressors including sedimentation stress, thermal stress, storm damage and overfishing, are constantly affecting reef health and community structure (Dubinsky and Stambler, 1996; Hatcher, 1997; Szmant, 2002).

Our results strongly demonstrate that $\alpha$-diversity is negatively correlated with the proximity to Stone Town. In addition, the overall reef condition and the calcium carbonate production show a negative correlation with increasing distance from Stone Town. Differences in reef condition between sites suggest that previously described human pressures have an impact on Zanzibar's reefs. Furthermore, reef-scape degradation (loss of three-dimensional coral architecture, live coral cover and aesthetics) could have slow-to-reverse effects on Zanzibar's economy. Strategic conservation measures like boat moorings or wastewater treatment plants would improve prospects for resilience by the reduction of anchor damage and reduction of particulate suspended solids, which in turn would maximize coral reef ecosystem functioning.

When protected versus unprotected reefs were compared, the CHICOP conservation area was suggested in the literature to be effective in preventing impacts from local human pressures on the reefs (Johnstone et al., 1998; Lokrantz et al., 2009). The hard coral community structure on CHICOP was consistently different to the community found at unprotected reefs. First of all, the biodiversity in CHICOP was higher than in the other study sites. Also, the branching coral genera that have high conservation value according to Edinger and Risk (2000), occurred in CHICOP. Secondly, CHICOP showed very high calcium carbonate production values when compared globally. Lastly, the conservation area showed a high percentage coral cover and a complex reef architecture. Nevertheless, whether or not these differences in biodiversity, coral cover and reef condition were driven by natural-local environmental factors and/or the current conservation efforts remains unclear because the distance from Stown Town work as a confounding factor given that there is no studies on reef status previous to the establishment of the MPA at Chumbe Reef. A better understanding of coral reef trajectories in the Zanzibar Archipelago could help provide information on the effect and effectiveness of protected areas on reef functionality and overall reef condition.

Nonetheless, all indices of reef condition indicate that remediation and protection efforts are likely to succeed on Prison Reef and Bawe Reef. Prison Island is one of the key sites for the tourism industry in the vicinity of Stone Town. For this reason, the protection of the reef should receive the highest conservation priority. We propose the implementation of measures that avoid mechanical damage (e.g., careless anchoring, tourists walking on the reef flat). Moreover, conservation measures should account for the subsistence needs of local people. Bawe Reef is an important fishing ground for local communities, because its intertidal platform provides women and children an area to harvest small invertebrates (Fröcklin et al., 2014), whereas fishermen use fishing-nets close to the reef. In addition, the easy access and location close to the main trade market makes this location attractive for seasonal fishermen (Jiddawi and Ohman, 2002). Therefore, the conservation effort should be in concordance to local community needs. It should reinforce reef functioning by following a two-dimensional approach (ecological and social).

The healthy reef condition indicated by the ecological and structural traits examined in this study, reinforce the importance of functionality of the ecosystem and the capacity to cope with natural and human-induced disturbances. Reef associated human activities, such as fisheries and tourism, substantially affect reef condition, development and health (Souter and Lindén, 2000). The negative effect of these activities is excluded in CHICOP, where we see a resilient reef ecosystem due to the functional biodiversity and the calcium carbonate budget. Large branching Acropora fields and large massive coral colonies found in CHICOP are fundamental in resilient carbonate budgets (Januchowski-Hartley et al., 2017). However, other human induced-disturbances such as the potential effect of untreated wastewater remain unclear. Such factors are extremely relevant because MPAs are, in most cases, unable to protect coral reef ecosystems from poor water quality. A better understanding of the biogeochemical properties of the water column, such as the seasonal variability or is crucial in constraining the environmental factors that control benthic assemblages.

\section{AUTHOR CONTRIBUTIONS}

HW conceived the project; NH, GN, and CR collected the field data, performed the statistical analyses and drafted the figures. $\mathrm{NH}, \mathrm{GN}, \mathrm{CR}$, and HW wrote the manuscript.

\section{ACKNOWLEDGMENTS}

This research was funded through the Leibniz Association in the frame of the Sustainable Uses of Tropical Areas (SUTAS) project. We are grateful to the Institute of Marine Science (IMS) in particular to C. Muhando, N. Jiddawi, S. Mukaka and Y. Shagude. This research could not be done without the field support from A. Eich, T. Mildenberger and J. Rehren, and with the support of the Geoecology and Carbonate Sedimentology group at ZMT.

\section{SUPPLEMENTARY MATERIAL}

The Supplementary Material for this article can be found online at: https://www.frontiersin.org/articles/10.3389/fmars. 2017.00412/full\#supplementary-material

Table S1 | Rank abundance raw data from the different taxon's encounter in our study sites. 
Figure S1 | Sampling effort: illustration of the abundance-based functional rarefaction. The solid line represents the mean cumulative values and the gray area its associated confidence interval.
Figure $\mathbf{S 2}$ | Bioerosion by encrustation and excavation of an aggressive and unclassified boring sponge on a massive coral at Prison Reef.

Figure S3 | Collapse and fall of large coral colonies at Prison Reef.

\section{REFERENCES}

Bellwood, D. R., Hughes, T. P., Folke, C., and Nyström, M. (2004). Confronting the coral reef crisis. Nature 429, 827-833. doi: 10.1038/nature 02691

Bruggemann, J. H., Kuyper, M. W. M., and Breeman, A. M. (1994b). Comparative analysis of foraging and habitat use by the sympatric Caribbean parrotfish Scarus vetula and Sparisoma viride (Scaridae). Mar. Ecol. Prog. Ser. 112, 51-66. doi: $10.3354 /$ meps 112051

Bruggemann, J. H., Van Kessel, A. M., Van Rooij, J. M., and Breeman, A. M. (1996). Bioerosion and sediment ingestion by the caribbean parrotfish Scarus vetula and Sparisoma viride: implications of fish size, feeding mode and habitat use. Mar. Ecol. Prog. Ser. 134, 59-71. doi: 10.3354/meps 134059

Bruggemann, J., Begeman, J., Bosma, E., Verburg, P., and Breeman, A. (1994a). Foraging by the stoplight parrotfish Sparisoma viride II. intake and assimilation of food, protein and energy. Mar. Ecol. Prog. Ser. 106, 57-71. doi: 10.3354/meps106057

Burke, L., Reytar, K., Spalding, M., and Perry, A. (2011). Reefs At Risk Revisited Executive Summary. Washington, D.C: World resources institute.

Cinner, J. E., McClanahan, T. R., Daw, T. M., Graham, N. A. J., Maina, J., Wilson, S. K., et al. (2009). Linking social and ecological systems to sustain coral reef fisheries. Curr. Biol. 19, 206-212. doi: 10.1016/j.cub.2008.11.055

Clarke, K. (1993). Non-parametric multivariate analyses of changes in community structure. Austr. Ecol. 18, 117-143. doi: 10.1111/j.1442-9993.1993. tb00438.x

Dubinsky, Z., and Stambler, N. (1996). Marine pollution and coral reefs. Glob. Chang. Biol. 2, 511-526. doi: 10.1111/j.1365-2486.1996. tb00064.x

Edinger, E. N. (1998). Effects of Land-Based Pollution on Indonesian Coral Reefs: Biodiversity, Growth Rates, Bioerosion and Application to the Fossil Record. Hamilton, ON: McMaster University.

Edinger, E. N., and Risk, M. J. (2000). Reef classification by coral morphology predicts coral reef conservation value. Biol. Conserv. 92, 1-13. doi: 10.1016/S0006-3207(99)00067-1

Edinger, E. N., Jompa, J., Limmon, G. V., Widjatmoko, W., and Risk, M. J. (1998). Reef degradation and coral biodiversity in Indonesia: effects of land-based pollution, destructive fishing practices and changes over time. Mar. Pollut. Bull. 36, 617-630. doi: 10.1016/S0025-326X(98) 00047-2

Edinger, E. N., Limmon, G. V., Jompa, J., Widjatmoko, W., Heikoop, J. M., and Risk, M. J. (2000). Normal coral growth rates on dying reefs: are coral growth rates good indicators of reef health? Mar. Pollut. Bull. 40, 404-425. doi: 10.1016/S0025-326X(99)00237-4

English, S., Wilkinson, C., and Baker, V. (1997). Survey Manual for Tropical Marine Resources. Townsville, QL: Australian Institute of Marine Science.

Fabricius, K. E. (2005). Effects of terrestrial runoff on the ecology of corals and coral reefs: review and synthesis. Mar. Pollut. Bull. 50, 125-146. doi: 10.1016/j.marpolbul.2004.11.028

Fabricius, K., and De'ath, G. (2001). Environmental factors associated with the spatial distribution of crustose coralline algae on the great barrier reef. Coral Reefs 19, 303-309. doi: 10.1007/s003380000120

Ferrario, F., Beck, M. W., Storlazzi, C. D., Micheli, F., Shepard, C. C., and Airoldi, L. (2014). The effectiveness of coral reefs for coastal hazard risk reduction and adaptation. Nat. Commun. 5:3794. doi: 10.1038/ncomms4794

Fox, J., and Weisberg, S. (2011). An R Companion to Applied Regression, 2nd Edn. Thousand Oaks, CA: Sage. Available online at: http://socserv.socsci.mcmaster. $\mathrm{ca} /$ jfox/Books/Companion

Fröcklin, S., De La Torre-Castro, M., Håkansson, E., Carlsson, A., Magnusson, M., and Jiddawi, N. S. (2014). Towards improved management of tropical invertebrate fisheries: including time series and gender. PLoS ONE 9:e91161. doi: 10.1371/journal.pone.0091161

Fuad, M. A. Z. (2010). Coral Reef Rugosity and Coral Biodiversity. Enschede, International Institute for Geo-Information Science and Earth Observation.

Gardner, T. A. (2003). Long-term region-wide declines in Caribbean corals. Science 301, 958-960. doi: 10.1126/science. 1086050

Glynn, P. W., and Manzello, D. P. (2015). "Bioerosion and coral reef growth: a dynamic balance," in Coral Reefs in the Anthropocene, ed C. Birkeland (Dordrecht: Springer), 67-97.

Graham, N. A. J., and Nash, K. L. (2013). The importance of structural complexity in coral reef ecosystems. Coral Reefs 32, 315-326. doi: 10.1007/s00338-012-0984-y

Graham, N. A. J., Wilson, S. K., Jennings, S., Polunin, N. V. C., Bijoux, J. P., and Robinson, J. (2006). Dynamic fragility of oceanic coral reef ecosystems. Proc. Natl. Acad. Sci. U.S.A. 103, 8425-8429. doi: 10.1073/pnas.06006 93103

Graham, N. A. J., Wilson, S. K., Pratchett, M. S., Polunin, N. V. C., and Spalding, M. D. (2009). Coral mortality versus structural collapse as drivers of corallivorous butterflyfish decline. Biodivers. Conserv. 18, 3325-3336. doi: 10.1007/s10531-009-9633-3

Grigg, R. W. (1994). Effects of sewage discharge, fishing pressure and habitat complexity on coral ecosystems and reef fishes in Hawaii. Mar. Ecol. Prog. Ser. 103, 25-34. doi: 10.3354/meps 103025

Hallock, P., Barnes, K., and Fisher, E. M. (2004). Coral-reef risk assessment from satellites to molecules: a multi-scale approach to environmental monitoring and risk assessment of coral reefs. Environ. Micropaleontol. Microbiol. Meiobenthol. 1, 11-39.

Harney, J. N., and Fletcher, C. H. (2003). A budget of carbonate framework and sediment production, Kailua Bay, Oahu, Hawaii. J. Sediment. Res. 73, 856-868. doi: 10.1306/051503730856

Hart, D. E., and Kench, P. S. (2007). Carbonate production of an emergent reef platform, Warraber Island, Torres Strait, Australia. Coral Reefs 26, 53-68. doi: 10.1007/s00338-006-0168-8

Hatcher, B. G. (1997). Coral reef ecosystems: how much greater is the whole than the sum of the parts? Coral Reefs 16, S77-S91. doi: 10.1007/s0033800 50244

Highsmith, C. (1981). Coral bioerosion: damage relative to skeletal density. Am. Nat. 117, 193-198. doi: 10.1086/283698

Hoegh-Guldberg, O., Mumby, P. J., Hooten, A. J., Steneck, R. S., Greenfield, P., Gomez, E., et al. (2007). Coral reefs under rapid climate change and ocean acidification. Science 318, 1737-1742. doi: 10.1126/science.1152509

Holmes, K. E., Edinger, E. N., Hariyadi Limmon G. V., and Risk, M. J. (2000). Bioerosion of live massive corals and branching coral rubble on Indonesian coral reefs. Mar. Pollut. Bull. 40, 606-617. doi: 10.1016/S0025-326X(00)00067-9

Huang, D., Benzoni, F., Fukami, H., Knowlton, N., Smith, N. D., and Budd A. F. (2014). Taxonomic classification of the reef coral families Merulinidae, Montastraeidae, and Diploastraeidae (Cnidaria: Anthozoa: Scleractinia). Zool. J. Linn. Soc. 171, 277-355. doi: 10.1111/zoj.12140

Hubbard, D. K., Miller, A. I., and Scaturo, D. (1990). Production and cycling of calcium carbonate in a shelf-edge reef system (St. Croix, U.S. Virgin Islands): applications to the nature of reef systems in the fossil record. J. Sediment. Petrol. 60, 335-360.

Hutchings, P. A. (1986). Biological destruction of coral reefs - a review. Coral Reefs 4, 239-252. doi: 10.1007/BF00298083

Januchowski-Hartley, F. A., Graham, N. A. J., Wilson, S. K., Jennings, S., and Perry, C. T. (2017). Drivers and predictions of coral reef carbonate budget trajectories. Proc. R. Soc. B 284:20162533. doi: 10.1098/rspb.2016.2533

Jiddawi, N. S., and Ohman, M. C. (2002). Marine fisheries in Tanzania. Ambio 31 , 518-527. doi: 10.1579/0044-7447-31.7.518

Johnstone, R. W., Muhando, C. A., and Francis, J. (1998). The status of the coral reefs of Zanzibar: One example of a regional predicament. Ambio 27, 700-707. 
Jokiel, P. L., Rodgers, K. S., Brown, E. K., Kenyon, J. C., Aeby, G., Smith, W. R., et al. (2015). Comparison of methods used to estimate coral cover in the Hawaiian Islands. PeerJ 3:e954. doi: 10.7717/peerj.954

Jones, N. S., Ridgwell, A., and Hendy, E. J. (2015). Evaluation of coral reef carbonate production models at a global scale. Biogeosciences 12, 1339-1356. doi: 10.5194/bg-12-1339-2015

Kaandorp, J. A. (1999). Morphological analysis of growth forms of branching marine sessile organisms along environmental gradients. Mar. Biol. 134, 295-306. doi: 10.1007/s002270050547

Kaandorp, J. A., and de Kluijver, M. J. (1992). Verification of fractal growth models of the sponge Haliclona oculata (Porifera) with transplantation experiments. Mar. Biol. 113, 133-143. doi: 10.1007/BF00367647

Kaandorp, J. A., Sloot, P. M. A., Merks, R. M. H., Bak, R. P. M., Vermeij, M. J. A., and Maier, C. (2005). Morphogenesis of the branching reef coral Madracis mirabilis. Proc. Biol. Sci. 272, 127-133. doi: 10.1098/rspb.2004. 2934

Kench, P. S., and Mann, T. (2017). Reef island evolution and dynamics: insights from the Indian and Pacific oceans and perspectives for the Spermonde Archipelago. Front. Mar. Sci. 4:145. doi: 10.3389/fmars.2017.00145

Kim, E., Lasker, H. R., Coffroth, M. A., and Kim, K. (2004). Morphological and genetic variation across reef habitats in a broadcast-spawning octocoral. Coelenterate Biol. 53, 423-432. doi: 10.1007/978-1-4020-2762-8_48

Kindt, R., and Coe, R. (2005). Tree Diversity Analysis. A Manual and Software for Common Statistical Methods for Ecological and Biodiversity Studies. Nairobi: World Agroforestry Centre (ICRAF).

Kruszynski, K. J., Kaandorp, J. A., and Van Liere, R. (2007). A computational method for quantifying morphological variation in scleractinian corals. Coral Reefs 26, 831-840. doi: 10.1007/s00338-007-0270-6

Lange, G. M., and Jiddawi, N. (2009). Economic value of marine ecosystem services in Zanzibar: Implications for marine conservation and sustainable development. Ocean Coast. Manag. 52, 521-532. doi: 10.1016/j.ocecoaman.2009.08.005

Lapointe, B. E., Thacker, K., Hanson, C., and Getten, L. (2011). Sewage pollution in Negril, Jamaica: Effects on nutrition and ecology of coral reef macroalgae. Chin. J. Oceanol. Limnol. 29, 775-789. doi: 10.1007/s00343-011-0506-8

Lesser, M. P., Weis, V. M., Patterson, M. R., and Jokiel, P. L. (1994). Effects of morphology and water motion on carbon delivery and productivity in the reef coral, Pocillopora damicornis (Linnaeus): Diffusion barriers, inorganic carbon limitation, and biochemical plasticity. J. Exp. Mar. Biol. Ecol. 178, 153-179. doi: 10.1016/0022-0981(94)90034-5

Lokrantz, J., Nyström, M., Norström, A. V., Folke, C., and Cinner, J. E. (2009). Impacts of artisanal fishing on key functional groups and the potential vulnerability of coral reefs. Environ. Conserv. 36, 327-337. doi: $10.1017 /$ S0376892910000147

Luckhurst, B. E., and Luckhurst, K. (1978). Analysis of the influence of substrate variables on coral reef fish communities. Mar. Biol. 49, 317-323. doi: 10.1007/BF00455026

Lwiza, K. M. M., and Bigendako, P. R. (1988). Kunduchi tides. Tanzania J. Sci. 4, 65-76.

Mallela, J., and Perry, C. T. (2006). Calcium carbonate budgets for two coral reefs affected by different terrestrial runoff regimes, Rio Bueno, Jamaica. Coral Reefs 26, 129-145. doi: 10.1007/s00338-006-0169-7

Mallela, J., Perry, C. T., and Haley, M. P. (2004). Reef morphology and community structure along a fluvial gradient, Rio Bueno, Jamaica. Caribb. J. Sci. 40, 299-311.

McClanahan, T. R., Ateweberhan, M., Graham, N. A. J., Wilson, S. K., Ruiz Sebastián, C., Guillaume, M. M. M., et al. (2007). Western Indian Ocean coral communities: bleaching responses and susceptibility to extinction. Mar. Ecol. Prog. Ser. 337, 1-13. doi: 10.3354/meps337001

Mgaya, Y. D. (1997). Global warming: a threat to human societies and natural ecosystems. Tanzan. J. Sci. 22, 23, 65-74.

Mohammed, M. S., and Mgaya, Y. D. (2001). "Nutrients levels and their dynamics in the coral reefs off Zanzibar Town," in Proceeding of Conference Advance Marine Science Tanzania IMS (UDSM, Tanzania), 171-183.

Mohammed, S. M., Muhando, C., and Machano, H. (2001). Assessment of Coral Reef Degradation in Tanzania: Results of Coral Reef Monitoring 1999. Coral Reef Degradation in the Indian Ocean (CORDIO). Vasteras: CORDIO East Africa.
Morgan, K. M., Perry, C. T., Smithers, S. G., Johnson, J. A., and Daniell, J. J. (2016). Evidence of extensive reef development and high coral cover in nearshore environments: implications for understanding coral adaptation in turbid settings. Sci. Rep. 6:29616. doi: 10.1038/srep29616

Moynihan, M. A., Baker, D. M., and Mmochi, A. J. (2012). Isotopic and microbial indicators of sewage pollution from Stone Town, Zanzibar, Tanzania. Mar. Pollut. Bull. 64, 1348-1355. doi: 10.1016/j.marpolbul.2012. 05.001

Muhando, C. A. (1998). The Status of Coral Reefs Around Zanzibar and the General Environmental Services they Provide. Coral Reefs: Values, Threats and Solutions. Zanzibar, Institute of Marine Science.

Muhando, C. A. (1999). Assessment of the Extent of Coral Damage, Socio-Economics Effects, Mitigation and Recovery in Tanzania. Coral Reef Degradation in the Indian Ocean (CORDIO). Stockholm: CORDIO East Africa.

Muhando, C. A., and Lanshammar, F. (2008). "Ecological effects of the crown-ofthorns starfish removal programme on Chumbe Island Coral Park, Zanzibar, Tanzania," in Proceeding of 11th International Coral Reef Symposium (Ft Lauderdale, FL).

Mukaka, D. S. (2014). Tides and Tidal Currents in the Zanzibar Channel. Dar es Salaam: University of Tanzania.

Mumby, P. J., Hedley, J. D., Zychaluk, K., Harborne, A. R., and Blackwell, P. G. (2006). Revisiting the catastrophic die-off of the urchin Diadema antillarum on Caribbean coral reefs: fresh insights on resilience from a simulation model. Ecol. Model. 196, 131-148. doi: 10.1016/j.ecolmodel.2005. 11.035

Mumby, P. J., and Steneck, R. S. (2008). Coral reef management and conservation in light of rapidly evolving ecological paradigms. Trends Ecol. Evol. 23, 555-563. doi: $10.1016 /$ j.tree.2008.06.011

Muzuka, A. N. N., Dubi, A. M., Muhando, C. A., and Shaghude, Y. W. (2010). Impact of hydrographic parameters and seasonal variation in sediment fluxes on coral status at Chumbe and Bawe reefs, Zanzibar, Tanzania. Estuar. Coast. Shelf Sci. 89, 137-144. doi: 10.1016/j.ecss.2010.05.007

National Bureau of Statistics (2012). Tanzania - Population and Housing Census 2012. Available online at: http://catalog.ihsn.org/index.php/catalog/4618

Newell, B. S. (1957). A Preliminary Survey of the Hydrography of the British East Africa Coastal waters. London, UK: Her Majesty's Stationery Office. Available online at: http://hdl.handle.net/1834/7218

Nordlund, L. M., Kloiber, U., Carter, E., and Riedmiller, S. (2013). Chumbe Island coral park-governance analysis. Mar. Policy 41, 110-117. doi: 10.1016/j.marpol.2012.12.018

Nyström, M., and Folke, C. (2001). Spatial resilience of coral reefs. Ecosystems 4, 406-417. doi: 10.1007/s10021-001-0019-y

Oksanen, J. (2015). Multivariate Analysis of Ecological Communities in R: vegan Tutorial. R Doc. Available online at: http://cc.oulu.fi/ jarioksa/opetus/metodi/ vegantutor.pdf

Perry, C. T., Edinger, E. N., Kench, P. S., Murphy, G. N., Smithers, S. G., Steneck, R. S., et al. (2012). Estimating rates of biologically driven coral reef framework production and erosion: a new census-based carbonate budget methodology and applications to the reefs of Bonaire. Coral Reefs 31, 853-868. doi: 10.1007/s00338-012-0901-4

Perry, C. T., Murphy, G. N., Graham, N. A. J., Wilson, S. K., JanuchowskiHartley, F. A., and East, H. K. (2015). Remote coral reefs can sustain high growth potential and may match future sea-level trends. Sci. Rep. 5:18289. doi: $10.1038 /$ srep 18289

Perry, C. T., Murphy, G. N., Kench, P. S., Smithers, S. G., Edinger, E. N., Steneck, R. S., et al. (2013). Caribbean-wide decline in carbonate production threatens coral reef growth. Nat. Commun. 4:1402. doi: 10.1038/ncomms2409

R Core Team (2010). R: A Language and Environment for Statistical Computing. Vienna: R Foundation for Statistical Computing. Available online at: http:// www.R-project.org/

R Core Team (2014). R: A Language and Environment for Statistical Computing. Vienna: R Foundation for Statistical Computing. Available online at: http:// www.R-project.org/

Riedmiller, S. (1998). The Chumbe Island Coral Park Project. A Case Study of Private Marine Protected Area Management: Partnership for Conservation. Report of the Regional Workshop on Marine Protected Areas, Tourism and Communities (Nairobi: IUCN EARO), 63-71. doi: 10.1038/35015610 
Roberts, C. M., McClean, C. J., Veron, J. E. N., Hawkins, J. P., Allen, G. R., McAllister, D. E., et al. (2002). Marine biodiversity hotspots and conservation priorities for tropical reefs. Science 295, 1280-1284. doi: $10.1126 /$ science. 1067728

Scoffin, T. P., Stearn, C. W., Boucher, D., Frydl, P., Hawkins, C. M., Hunter, I. G., et al. (1980). Calcium carbonate budget of a fringing reef on the west coast of Barbados: Part II, Erosion, sediments and internal structure. Bull. Mar. Sci. 30, 475-508.

Sebens, K. P., Witting, J., and Helmuth, B. (1997). Effects of water flow and branch spacing on particle capture by the reef coral Madracis mirabills (Duchassaing and Michelotti). J. Exp. Mar. Biol. Ecol. 211, 1-28. doi: 10.1016/S0022-0981(96)02636-6

Shaghude, Y. W., and Wannäs, K. O. (2000). Mineralogical and biogenic composition of the Zanzibar channel sediments, Tanzania. Estuar. Coast. Shelf Sci. 51, 477-489. doi: 10.1006/ecss.2000.0686

Shaghude, Y. W., Wannäs, K. O., and Mahongo, S. B. (2002). Biogenic assemblage and hydrodynamic settings of the tidally dominated reef platform sediments of the Zanzibar Channel. West Ind. Ocean J. Mar. Sci. 1, 107-116. Available online at: https://www.oceandocs.org/bitstream/handle/1834/32/WIOJ12107. pdf?sequence $=1$

Souter, D. W., and Lindén, O. (2000). The health and future of coral reef systems. Ocean Coast. Manag. 43, 657-688. doi: 10.1016/S0964-5691(00) 00053-3

Storlazzi, C. D., Field, M. E., Dykes, J. D., Jokiel, P. L., and Brown, E. (2002). "Wave control on reef morphology and coral distribution: Molokai, Hawaii" in Fourth International Symposium on Ocean Wave Measurement and Analysis (San Francisco, CA).

Szmant, A. M. (2002). Nutrient enrichment on coral reefs: Is it a major cause of coral reef decline? Estuaries 25, 743-766. doi: 10.1007/BF02804903

Todd, P. A. (2008). Morphological plasticity in scleractinian corals. Biol. Rev. 83, 315-337. doi: 10.1111/j.1469-185X.2008.00045.x

Tudhope, A. W., and Scoffin, T. P. (1994). Growth and structure of fringing reefs in a muddy environment, South Thailand. J. Sediment Res. Sect. A 64, $752-764$.

Vecsei, A. (2001). Fore-reef carbonate production: Development of a regional census-based method and first estimates. Palaeogeogr. Palaeoclimatol. Palaeoecol. 175, 185-200. doi: 10.1016/S0031-0182(01)00371-6
Venables, W. N., and Ripley, B. D. (2002). Modern Applied Statistics with S. Issues of Accuracy and Scale. New York, NY: Springer-Verlag.

Vermeij, M. J. A., Dailer, M. L., and Smith, C. M. (2011). Crustose coralline algae can suppress macroalgal growth and recruitment on Hawaiian coral reefs. Mar. Ecol. Prog. Ser. 422, 1-7. doi: 10.3354/meps08964

Veron, J. E. N. (2000). Corals of the World. Townsville, QL: Australian Institute of Marine Science.

Veron, J. E. N. (2002). New Species Described in Corals of the World. Townsville, QL: Australian Institute of Marine Science Monograph Series.

Veron, J. E. N., Devantier, L. M., Turak, E., Green, A. L., Kininmonth, S., StaffordSmith, M., et al. (2009). Delineating the coral triangle. Galaxea J. Coral Reef Stud. 11, 91-100. doi: 10.3755/galaxea.11.91

Vroom, P. S. (2011). "Coral Dominance": a dangerous ecosystem misnomer? J. Mar. Biol. 2011, 1-8. doi: 10.1155/2011/164127

Webb, A. P., and Kench, P. S. (2010). The dynamic response of reef islands to sealevel rise: evidence from multi-decadal analysis of island change in the central Pacific. Glob. Planet. Change 72, 234-246. doi: 10.1016/j.gloplacha.2010.05.003

Wickham, H. (2009). ggplot2: Elegant Graphics for Data Analysis. New York, NY: Springer-Verlag.

Wilkinson, C. (2008). Status of Coral Reefs of the World: 2008. Townsville, QL: Global Coral Reef Monitoring Network and Reef and Rainforest Research Center.

Wolanski, E., Richmond, R., McCook, L., and Sweatman, H. (2003). Mud, marine snow and coral reefs: the survival of coral reefs requires integrated watershedbased management activities and marine conservation. Am. Sci. 91, 44-48. doi: $10.1511 / 2003.1 .44$

Conflict of Interest Statement: The authors declare that the research was conducted in the absence of any commercial or financial relationships that could be construed as a potential conflict of interest.

Copyright $\odot 2017$ Herrán, Narayan, Reymond and Westphal. This is an open-access article distributed under the terms of the Creative Commons Attribution License (CC $B Y$ ). The use, distribution or reproduction in other forums is permitted, provided the original author(s) or licensor are credited and that the original publication in this journal is cited, in accordance with accepted academic practice. No use, distribution or reproduction is permitted which does not comply with these terms. 